\title{
HET LEWINSKY-SCHANDAAL
}

\author{
VAN PEKELZONDE TOT IMPEACHMENT
}

\section{Inleiding: de voorwaarden voor een schandaal}

Begin I998 barstte in de Verenigde Staten het Lewinsky-schandaal los, dat minstens zoveel met de Amerikaanse president Bill Clinton als met Monica Lewinsky te maken had. 'Lewinskygate' heette het korte tijd omineus, alsof het land weer op zijn grondvesten zou gaan schudden. Had Clinton zijn eed van trouw aan de Grondwet geschonden? Deden de Republikeinen met hun overreactie een poging tot staatsgreep, zoals wel werd gezegd? Het viel mee. Het schandaal werd nooit meer dan 'Zippergate', een uiterst pijnlijke affaire die Clinton en het presidentschap beschadigde, maar constitutioneel gezien met een sisser afliep. De ingrediënten waren een amoureuze relatie tussen Clinton en een stagiaire, een knullige operatie tot verhulling van wat er was gebeurd, verraad binnen de vriendenkring van de vrouwelijke hoofdpersoon en een 'independent counsel' die minder onbevangen was dan zijn titel suggereerde. Deze functionaris, Kenneth Starr, leek vooral politiek gemotiveerd om als een bloedhond achter Clinton aan te gaan. ${ }^{\mathrm{I}}$ Verder was er natuurlijk Clintons echtgenote, Hillary Rodham. Hoe zou zij, zelfbewust, trots en dus zichtbaar ongemakkelijk in de rol van slachtoffer, de zaak aanpakken? De First Lady hield zich groot, verklaarde niet van het 'Stand by your man'-type te zijn, maar liet Bill niet vallen. Even dook het spook van afzetting op. Tenslotte echter kwam de meerderheid van de Senaat - nadat het Huis van Afgevaardigden inderdaad tot 'impeachment' had besloten - bij zijn positieven en besloot het niet zover te laten komen.

Einde verhaal, of waren er blijvende gevolgen? Het Lewinsky-schandaal schokte nog lang na. Vooral in de nasleep van '9/II' haalden de Republikeinen het weer uit de kast, om de schuld voor het falende antiterrorismebeleid op Clinton af te schuiven, de man die zijn hoofd bij andere dingen zou hebben gehad toen Bin Laden aangepakt had moeten worden. Doorzichtige manoeuvres. Wat de Republikeinen ook deden, het schandaal wilde ook achteraf niet uitdijen tot de ooit beoogde proporties.

Dit artikel doet een poging het schandaal in relevante factoren te ontleden. Hoe kwam het dat een reeks van gebeurtenissen die even het einde van Clintons 
presidentschap leek aan te kondigen, in een anticlimax eindigde? Wat was er nodig om de 'affaire-Lewinsky' eerst te laten uitdijen tot een echt schandaal en daarna weer te laten wegebben? Welke rol speelden de media? Bevestigt hun functioneren in het Lewinsky-schandaal de stelling van James Lull en Stephen Hinerman dat 'managers of modern news media actively try to turn stories into scandals'? ${ }^{2}$ Het antwoord lijkt 'nee' te moeten zijn. Als de media zich met dit goud in hun handen conform de hun toegedichte natuur hadden uitgeleefd, had Clinton zijn presidentschap vroegtijdig moeten neerleggen.

Of een affaire de dimensies van een schandaal krijgt, hangt af van verscheidene factoren. Amerikanen, met hun - gemiddeld genomen - nog altijd puriteinse inslag, spitsen bij de woorden 'buitenechtelijke affaire' meer de oren dan de meeste Europeanen. ${ }^{3}$ Voor de affaire-Lewinsky was dit een voorwaarde om tot een waar schandaal uit te groeien. Meer conjunctureel van aard was de politieke context. De Republikeinen zonnen op wraak voor de nederlagen bij de verkiezingen van I992 en I996. Want wie had na de grote successen van president George H.W. Bush (I989-I993), zoals de val van het Sovjet-rijk en de victorie in de Golfoorlog van I99I, kunnen dromen dat hij door een Democratische gouverneur van Arkansas zou worden verslagen? Clinton mocht vroeg of laat een afstraffing verwachten. Daar kwam nog de overgevoeligheid voor 'serious misconduct in office' bij, die heel Amerika door de Watergate-affaire (I972-I974) had opgelopen. Dat Richard Nixon zich ernstig had misdragen en daardoor in aanmerking kwam voor 'impeachment', moest indertijd zelfs door de Republikeinen worden erkend. Niettemin beidden zij hun tijd en wachtten op een kans te bewijzen dat dit soort kwaad niet typisch was voor hun partij, maar in de Democratische Partij net zo goed kon voorkomen. ${ }^{4}$ President Clinton vormde wat dat betreft een geschikt doelwit. De strijd rond zijn in Republikeinse ogen impeachment-waardige 'high crimes and misdemeanors' (zoals het 'misconduct' dat een president fataal kan worden in artikel 2 van de Grondwet wordt omschreven) zou het land niet te gronde richten, maar wel Clintons partij ernstig in diskrediet brengen. ${ }^{5}$ Hier leek zich, kortom, een veilige, 'splendid little war' aan te dienen, met de Republikeinen als zekere winnaars. Precies het soort strijd waarop zij aasden.

Tegen alle verwachtingen in voltrok zich een heel ander scenario. Het publiek bleek voor deze zaak niet echt warm te lopen en begon zich op een gegeven moment ernstig te storen aan de meedogenloosheid waarmee de president door de 'independent counsel' en de Grand Old Party werd achtervolgd. ${ }^{6}$ Zo kwam het dat het Lewinsky-schandaal bij de verkiezingen van I998 juist negatief voor de oppositie uitpakte. Ook toen in 2000 na acht jaar de balans van het presidentschap van Clinton moest worden opgemaakt had het, heel anders dan 'Watergate' in I976 had gedaan, per saldo weinig invloed op de uitslag van de verkiezingen. Weliswaar werd George W. Bush gekozen, maar dat lag meer aan de zwakte van de democratische kandidaat Al Gore dan aan wijd verbreide afkeer van het 'ancien régime'. De vonk van de oprechte haat die veel 
Republikeinen jegens de 'Sixties Children' rond Clinton koesterden, was niet overgesprongen op de massa. De persoonlijke populariteit van Clinton had nauwelijks geleden. Het was zelfs alsof zijn nogal onbeholpen verdediging tegen de beschuldigingen, in samenhang met het uitgekiende en fanatieke gedrag van zijn tegenstanders, hem nog meer dan vroeger tot object van identificatie had gemaakt. Een echt mens, wie niets menselijks vreemd is; een groot kind met het hart op de goede plaats: met dat imago sloot Clinton zijn turbulente tweede ambtstermijn af.

\section{De president en de stagiaire}

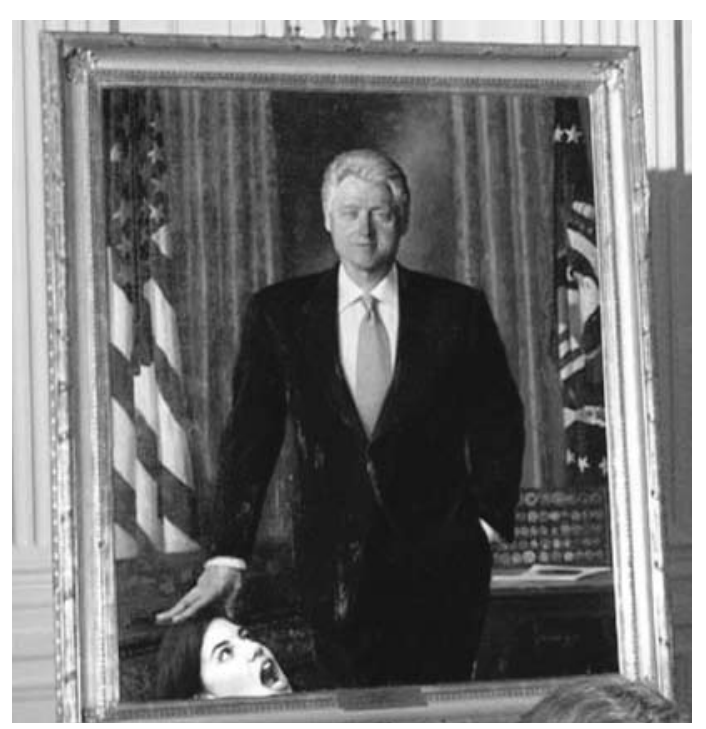

Bron: Internet, evenals alle andere afbeeldingen in dit artikel

Het is inherent aan een geheime liefdesaffaire dat niet alle feiten aan de buitenwereld bekend zijn. Wat er in de 'Lewinsky-affaire' werkelijk toe deed is echter redelijk geboekstaafd.?

Monica Lewinsky begon in de zomer van I995 als 2I-jarige stagiaire ('intern') bij het Witte Huis, op het kantoor van 'stafchef' Panetta. Haar werkplek was toen nog niet feitelijk in het Witte Huis zelf, maar in het naastgelegen - en via een ondergronds gangenstelsel met het Witte Huis verbonden - 'Old Executive Office Building’. Deze logischerwijs felbegeerde positie had zij te danken aan een goed woordje van een kennis die vriendschappelijke banden onderhield met leden van de regering. Later dat jaar kreeg zij daar een echte baan, als medewerkster van het 'Legislative Affairs Office', een bureau dat onder meer de contacten met de wetgevende macht onderhield. Achteraf is natuurlijk de vraag gesteld of Clinton - 'l'affaire' was toen net begonnen - haar die baan had bezorgd, maar daarvan is niets gebleken. Hoe dan ook, zij werkte nu onder hetzelfde dak als Clinton.

Plagerij van de toentertijd in meerderheid Republikeinse volksvertegenwoordiging creëerde het toeval dat de president en de stagiaire in elkaars armen dreef. In november I995 ontstond er in de loopgravenoorlog tussen de wetgevende en de uitvoerende macht weer eens een conflict over de begroting. Doordat er officieel geen geld meer was om de federale overheid te laten functioneren - een kwestie van een om politieke redenen vertraagde appropriations act - zag zelfs het Witte Huis zich genoodzaakt al het personeel naar huis te sturen, op de onbetaalde stagiair(e)s na. Zo is het gekomen. In de gegeven omstandigheden heerste er een ongedwongen sfeer van verbroedering. Hoog 
en laag leerden elkaar ineens persoonlijk kennen. Op I5 en I6 november I995 hadden Clinton en Lewinsky in een verder vrijwel leeg gebouw, waar alleen wat onmisbare topfunctionarissen en verloren vrijwilligers ronddwaalden, hun eerste intieme ontmoetingen. Het bleef niet bij praten en elkaar diep in de ogen kijken, maar zij gingen ook niet 'all the way'. In de maanden daarna gebeurde dit vaker, ook toen de regering weer normaal functioneerde. Hoe ver Clinton en Lewinsky daarbij wel of niet gingen blijft hier verder onbesproken, want hoewel er wel een ontwikkeling in hun relatie zat - de sigaar, de bevlekte jurk; het is allemaal uit en te na in de pers geweest en bespot - was die niet cruciaal voor het schandaal op zich.

In het voorjaar van 1996 begonnen de ontmoetingen van Clinton en Lewinsky in kringen rond de president zozeer in de gaten te lopen, dat leden van zijn staf zich in stilte beraadden over maatregelen. Hun chef moest tegen zichzelf worden beschermd, dat was duidelijk. Onschuldig achtte men Clinton met zijn slordig gecontroleerde libido niet, maar van Lewinsky had men ook geen hoge dunk. Zij hing volgens de presidentiële entourage teveel rond op plekken waar zij niet hoorde en drong zich op. ${ }^{8}$ Tegen haar zin werd Lewinsky in april overgeplaatst naar het Pentagon. Kort daarvoor had Clinton de relatie officieel verbroken, maar vrijwel onmiddellijk daarna weer hersteld. Met Monica op Defensie in plaats van om de hoek werd het echter lastig nog ontmoetingen zo toevallig te laten plaatsvinden als voor de geheimhouding nodig was. Telefoongesprekken en telefoonseks waren het alternatief.9 Lewinsky drong er bij Clinton veelvuldig op aan haar weer een baan in het Witte Huis te bezorgen, wat deze halfhartig toezegde. Hij had het desgewenst snel kunnen regelen, maar deed het niet, wellicht bang voor de consequenties. Het heeft er alle schijn van dat de relatie wat hem betrof vooral van seksuele aard was, maar bij Lewinsky stoelde op oprechte verliefdheid. Zij begreep dan ook niet waarom hij de boot steeds meer afhield. Er vond nog sporadisch een rendez-vous plaats, totdat Clinton haar op 24 mei 1997 definitief de bons gaf.

Waarschijnlijk was deze timing geen toeval. De president raakte juist op dat moment verstrikt in een door een zekere Paula Jones aangespannen sexual harassment-zaak. Als zijn liaison met Monica Lewinsky bekend werd - en er waren aanwijzingen dat Monica haar kaken niet stijf op elkaar hield - zou dat desastreus kunnen uitpakken voor zijn verdediging in de zaak-Jones. Een president die het blijkt aan te leggen met een jonge stagiaire staat zwak als hij zich moet verweren tegen de aantijging dat hij zijn hormonen niet in bedwang kan houden. De advocaten van Jones belaagden Clinton met dagvaardingen om de namen te noemen van alle vrouwen met wie hij had gescharreld. $\mathrm{Zij}$ wilden een patroon aantonen dat Jones' claim geloofwaardig zou maken. Onder die omstandigheden kon Clinton Lewinsky maar beter zo ver mogelijk uit de buurt houden.

De afgewezen stagiaire liet zich echter niet afschepen. In tegendeel; wat volgde was een periode waarin zij Clinton juist onder druk zette om de relatie te herstellen en daarnaast eindelijk eens werk te maken van die andere baan 
voor haar. Het begon op chantage te lijken. Op 3 juli schreef zij hem bijvoorbeeld een brief waarin zij hem (deze keer aangesproken met 'Dear Sir', in plaats van het vroegere 'Handsome') liet weten dat als zij niet spoedig weer in het Witte Huis tewerkgesteld zou worden, zij haar ouders zou vertellen 'exactly why that wasn't happening'. ${ }^{\text {Io }}$ Steeds meer mensen raakten intussen op de hoogte van wat er gaande was. Terwijl Clinton en zijn advocaten op het Jones-front alle zeilen moesten bijzetten, beijverden zij zich tegelijk om Lewinsky de mond te snoeren. Uitsluitend om die reden had de president later toch nog een paar ontmoetingen met haar. Op haar smeekbede alles weer als vroeger te laten zijn ging hij niet in, maar hij deed wel een dringend beroep op haar solidariteit. Als zij zou moeten getuigen in de Jones-zaak, diende ze tot het uiterste te gaan om de waarheid over haar eigen relatie met Clinton te verhullen. Daarmee waagde hij zich op het gladde ijs van mogelijke 'obstruction of justice', een element in het schandaal dat door Kenneth Starr tot op het bot zou worden afgekloven.

\section{Kenneth Starr}

Wat was de taak van de 'independent counsel' en wie was Kenneth Starr?

Tijdens het Watergate-schandaal, dat de ondergang werd van president Nixon (1969-1974), had de uitvoerende macht meermalen geprobeerd in te grijpen in onderzoek van het Openbaar ministerie. Toen de grond te heet werd onder hun voeten hadden Nixon en zijn staf zelfs lastige 'prosecutors' onschadelijk gemaakt door hen te ontslaan en daarna zelf hun vervangers aan te stellen. Zo hoopten zij het onderzoek te kunnen bijsturen. Na Watergate was het voorkómen van dit soort willekeur een van Amerika's prioriteiten. De wet van I978 die het ambt van 'special prosecutor' of 'independent counsel' instelde (de 'Ethics in Government Act'), vloeide rechtstreeks voort uit het opgelopen trauma. Voortaan was het onmogelijk dat de uitvoerende macht zelf degene benoemde die haar functioneren aan de wet toetste. Als een belangrijke overheidsfunctionaris strafrechtelijk of constitutioneel in opspraak zou komen, zou een onafhankelijke 'counsel' een onderzoek instellen en al dan niet tot

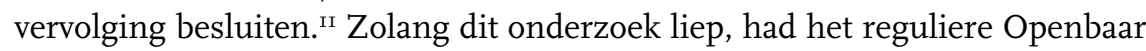
ministerie (dat in zekere zin deel is van de uitvoerende macht) geen zeggenschap over de zaak, want de 'independent counsel' bezat voor de duur van zijn opdracht 'full power and authority to exercise all investigative and prosecutorial functions and powers of the Department of Justice, the Attorney General, and any other officer of the Department of Justice'. ${ }^{12}$ De 'counsel' moest na met een bijna blanco volmacht zijn werk te hebben gedaan, aan het Congres rapporteren of hij gronden zag voor 'impeachment'.

Kenneth Starr onderzocht aanvankelijk de Whitewater-affaire in Arkansas, een zaak die draaide om onroerend goed en politieke patronage, waarbij ook de 
Clintons zijdelings betrokken waren. Hun relatie met deze kwestie was de reden geweest überhaupt tot benoeming van een 'special prosecutor' over te gaan. Het onderzoek betrof daardoor immers mede het handelen van de president van de Verenigde Staten - weliswaar in diens vorige leven als gouverneur van Arkansas. ${ }^{13}$ Dat juist Starr het Whitewateronderzoek ging leiden voorspelde al niet veel goeds. Zijn advocatenkantoor, Kirkland \& Ellis, was indirect partij in de zaak van Paula Jones. De speciale commissie die de 'independent counsel' benoemde, voorgezeten door een politieke vriend van de ultrarechtse Senator Jesse Helms, schoof de kandidaat van de minister van Justitie opzij en benoemde Starr. De commissie ${ }^{14}$ had het volste recht dat te doen, want het idee achter de ingewikkelde benoemingsprocedure - die door de 'Chief Justice' werd gesuperviseerd - was nu juist dat de minister van Justitie niet het laatste woord moest hebben. Maar haar beslissing was niet vrij van politieke overwegingen en dus omineus voor de Clintons..$^{15}$

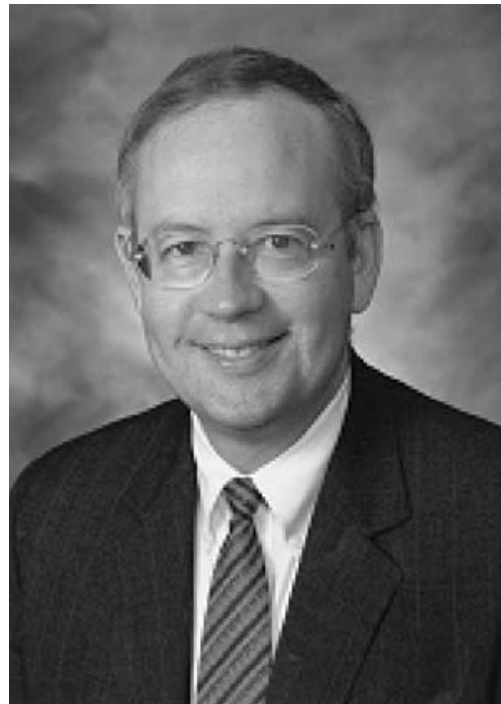

Kenneth Starr

Nadat een vriendin van Lewinsky hem had verteld over Clintons overspel, breidde Starr zijn zoektocht naar belastend materiaal uit naar wat het Lewinsky-schandaal zou worden. Door bij de president een patroon van leugens en bedrog bloot te leggen hoopte hij mede de Whitewater-zaak te kunnen oplossen. De manier waarop hij dat deed, getuigde volgens velen van een overspannen opvatting van zijn taak, van partijdigheid en vooringenomenheid, van een schijnheilige, maniakale fascinatie voor seks en/of van juridische onkunde. ${ }^{16}$ Uiteraard waren er ook mensen die hem verdedig(d)en. Tal van Republikeinse commentatoren die niets van Clinton moesten hebben namen Starr alleen daarom al in bescherming. Maar ook een objectieve juridische studie als Starr: A Reassessment van Benjamin Wittes neemt het enigszins voor hem op, in zoverre deze hem vrijpleit van partijdigheid. Wittes ziet Starrs bevlogenheid voortkomen uit een nobel, maar helaas onjuist streven 'het ware verhaal' te vertellen, alsof hij de rol van een soort eenpersoons-waarheidscommissie moest spelen. Daar viel ook het seksleven van Clinton onder, hoewel dit - volgens Wittes - juridisch irrelevant was. Zelfs Clintons meineed in de zaak-Jones (zie hieronder) rechtvaardigde Starrs spektakel niet; die zei alleen iets over het karakter van de president en had geen constitutionele betekenis. Wittes concludeert dat Starr zichzelf beter als een gewone aanklager met bijzondere bevoegdheden had kunnen beschouwen. Anders dan een schrijver of journalist die in het kader van zijn research elk kronkelpad mag bewandelen, dient ook een 'independent counsel' alle normale juridische procedures in acht te nemen. ${ }^{17}$ Nobele motieven of niet, mede als gevolg van Starrs optreden is de wet die de benoeming van een 'independent counsel' mogelijk maakte, niet verlengd en dus vervallen. 
TYWLEAKERLINDA TRRIPP.

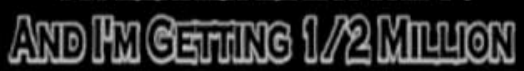
OFYOURTAR DOLLARSD

AllHatNocartienct 11-4-03

\section{Een sinistere rol voor Linda Tripp}

Hier betreedt de boze fee in het verhaal, Linda Tripp, het toneel. De beeldvorming van Tripp heeft extra geleden onder het feit dat zij weinig uiterlijke charme bezit. In een zwart sprookje als dit horen slachtoffers en daders, helden en schurken scherp te worden onderscheiden, anders klopt er iets niet. Lewinsky was sowieso te jong, te mooi, te aardig en te onbevangen om dader te zijn. Ook Clinton met zijn opzichtige en daardoor bijna vertederende manier van zondigen was te aaibaar om als schurk te worden ontmaskerd. Zo was die rol als vanzelf weggelegd voor Linda Tripp. Deze vrouw pleegde immers om politieke redenen, of om bij haar superieuren in een goed blaadje te komen, verraad jegens een vriendin. Haar minder aantrekkelijke voorkomen leende zich ook nog eens goed voor vileine kritiek en spot. ${ }^{18}$

Het valt moeilijk haar tegen dit volksgericht in bescherming te nemen, want haar optreden was inderdaad weinig verheffend. Lewinsky had Tripp op het Pentagon leren kennen en het een en ander over haar avonturen met Clinton laten doorschemeren. Dat deed zij bij meer kennissen. Achteraf is bekend geworden dat Lewinsky tegenover een hele reeks van mensen (minstens elf), onder wie haar ouders, loslippig is geweest. (Misschien zonder in details te treden, maar toch zo open dat het een wonder was dat er niet veel eerder schandaal van kwam.) Hoe dan ook, Tripp zag haar kans schoon om Lewinsky, die haar blindelings vertrouwde, steeds meer geheimen te ontlokken. Toen zij voldoende had gehoord om te beseffen dat er een grote affaire inzat, legde ze de gesprekken met Lewinsky in het geheim op de band vast. Deze praatsessies vonden plaats in het Ritz-Carlton Hotel in Arlington, aan de overkant van de Potomac, vlakbij het Pentagon en daarom ook wel 'the Pentagon Ritz' genoemd. Naderhand spraken mensen van 'Ground Zero of the Lewinsky Scandal'.

De cassettebanden droeg Tripp daarna eerst over aan een journalist van Newsweek, daarna aan de conservatieve commentator Lucianne Goldberg, toen aan de advocaten van Paula Jones en tenslotte aan Starr, waarmee ze hem het rokende pistool toespeelde. Starr realiseerde zich onmiddellijk dat hij beet had. Hij zou Clinton confronteren met wat hij wist, of via zijn informante nog meer te weten komen. Tijdens de laatste gesprekken met Lewinsky, in januari I998, kon Tripp haar eigen cassetterecorder thuis laten. Zij was op aanbeveling van Starr door de FBI van geavanceerde afluisterapparatuur voorzien ('wired'); FBImedewerkers luisterden op een hotelkamer mee en namen alles op. Tijdens het allerlaatste gesprek stormden mensen van dе ғв в het restaurant binnen, namen Lewinsky mee naar hun kamer en confronteerden haar met de feiten. Zij kon 
nu maar beter meewerken en haar verhaal doen. Lewinsky kreeg in ruil daarvoor vrijwaring van vervolging aangeboden - zij had inmiddels als getuige in de Paula Jones-zaak op diens aandrang gelogen over haar relatie met Clinton. ${ }^{\text {I9 }}$

\section{In de openbaarheid}

Januari I998 werd voor de president in meer opzichten een desastreuze maand. Op de 2ie verscheen in The Washington Post het eerste krantenartikel in een lange reeks van sappige nieuwsberichten en onthullingen. ${ }^{20}$ 'Clinton Accused of Urging Aide to Lie; Starr Probes Whether President Told Woman to Deny Alleged Affair to Jones's Lawyers', luidde de kop. ${ }^{21}$ In de omgeving van Clinton brak paniek uit. Wie wist of vermoedde dat er iets van waar was brak zich het hoofd over 'damage control'; wie zich niet kon voorstellen dat de president op deze manier over de schreef was gegaan maakte zich niettemin ernstige zorgen over de gevolgen. Robert Bennett, de advocaat van Clinton in de Jones-zaak en dus vermoedelijk wel op de hoogte van de belangrijkste feiten, verklaarde: 'This story seems ridiculous and I frankly smell a rat'. ${ }^{22}$ Kortom: 'valse beschuldigingen, op politieke gronden'. Deze boodschap was deels niet onjuist, want het politieke opportunisme van Starr speelde waarschijnlijk wel een rol, maar zo reageren was ook een zwaktebod van mensen die niet meer wisten waar zij het zoeken moesten.

Weinigen hielden het hoofd koel. De president zelf beging in deze maand zijn grootste fouten. Juridisch het schadelijkst was een getuigenis onder ede in de Jones-zaak (een 'deposition', afgelegd ten overstaan van een rechter die hiervoor vanuit Little Rock, Arkansas, naar Washington was overgekomen), waarin hij tegensprak een 'sexual affair' of 'sexual relations' met Lewinsky te hebben gehad. Moreel onhoudbaar was zijn ontkenning van de affaire tegenover zijn eigen kabinet. De door hemzelf benoemde ministers, in veel gevallen oude strijdmakkers en trouwe aanhangers, aanvaardden zijn uitleg, spraken in de openbaarheid hun steun aan de president uit en voelden zich verraden toen later de waarheid bekend werd. Publicitair funest waren Clintons ontkenningen in een interview voor National Public Radio (NPR) op 2I januari, een gesprek op diezelfde dag in THE NEWS HOUR WITH JIM LEHRER, een door velen bekeken televisieprogramma van Public Broadcasting Service (PBS) en - als hoogtepunt - een met een mengeling van angst en boosheid uitgesproken openbare verklaring van 26 januari. In de Roosevelt Room van het Witte Huis zei de president:

'I want to say one thing to the American people. I want you to listen to me. I'm going to say this again: I did not have sexual relations with that woman, Miss Lewinsky. I never told anybody to lie, not a single time. Never. These allegations are false. ${ }^{23}$ 
In The Chicago Tribune van 27 januari stond het volgende over de vertoning te lezen: 'A defiant President Clinton wagged his finger at the cameras and thumped the lectern Monday as he insisted he did not have sex with a young White House intern or ask her to deny it under oath. ${ }^{24}$ Hoe vaak zijn de beelden van de president toen hij deze woorden sprak niet op de televisie herhaald? Voor Lewinsky deed deze scène de deur dicht. Zij had haar nek uitgestoken - gelogen - om Clinton te sauveren en nu sprak hij denigrerend over haar als 'that woman'. Vanaf dit moment was er weinig beletsel meer om primair haar eigen huid te redden en serieus met Starr te onderhandelen over 'immunity' (vrijwaring van vervolging).

Clinton de politicus was het spoor even helemaal bijster geweest. Zijn eigen vrouw Hillary had hij niet eens op de hoogte gesteld van wat er echt was gebeurd, want zij sprak in de TODAY-show van NBC van een 'enorme rechtse samenzwering' tegen haar man, een poging 'to undo the results of two elections'. ${ }^{25}$ Als zij de feiten had gekend had zij dit zeker niet gedaan. Dit bleek wel toen Hillary in augustus diep door het stof moest. Hoewel zij ook na zijn (eerst) privébekentenis en zijn (daarna) openbare bekentenis achter hem bleef staan, maakte zij duidelijk zich dubbel vernederd te voelen: door zijn ontrouw én doordat hij geen open kaart had gespeeld. ${ }^{26}$

\section{Het net sluit zich}

I998 was een verkiezingsjaar. Alle zetels in het Huis van Afgevaardigden en een-derde van het aantal Senaatszetels stond op het spel. Met een seksaffaire rond het Witte Huis was nog niet eerder ervaring opgedaan. Affaires genoeg natuurlijk-Nixons Watergate en het Iran-Contra-schandaal onder Reagan lagen vers in het geheugen - maar hoe het publiek zou reageren op de avonturen van een grijzende president met een jonge stagiaire was ongewis. De Republikeinen hadden hun calculatie echter snel gemaakt en verwachtten er alleen maar garen bij te kunnen spinnen. Hun strategie was: maximale winst door maximale beschadiging van de president, binnen de grenzen van de rechtsstaat.

Het zelfvertrouwen in het Republikeinse kamp was groot. In I994 hadden zij zowel in het Huis van Afgevaardigden als in de Senaat een meerderheid verworven. In het Huis was dat voor het eerst sinds veertig jaar. Hun verkiezingsprogramma ten tijde van deze 'Republican Revolution', het 'Contract with America' dat alles waar Clinton voor stond afwees, was ook in de periode daarna bron van inspiratie gebleven. In I996 was Clinton weliswaar herkozen, maar de Republikeinen behielden hun meerderheid in de volksvertegenwoordiging. Bij de nadering van de verkiezingen van I998 verwachtten zij niet anders dan dat zij opnieuw het mandaat zouden krijgen hun 'Contract with America' verder te implementeren. De geschiedenis wees ook in die richting. Al driekwart eeuw had de oppositiepartij winst geboekt bij 'mid-term elections' (verkiezingen in 
een jaar waarin geen president wordt gekozen) en dit effect had zich nog sterker (namelijk al anderhalve eeuw) voorgedaan als de zittende president aan zijn tweede termijn bezig was. Clintons problemen met het Lewinsky-schandaal namen de laatste twijfel weg.

Aanvankelijk voltrok dit droomscenario van de Republikeinen zich volgens plan. Clinton moest steeds meer terrein prijsgeven, wat hem ertoe bracht voortaan zo min mogelijk over de zaak-Lewinsky zelf te zeggen en vooral te benadrukken dat hij het van de kiezers ontvangen mandaat niet zou opgeven. Aftreden? Geen denken aan. Op één punt nam het lot een gunstige wending voor de president. De rechter in de Jones-zaak wees de voornaamste civiele claims jegens Clinton af. ${ }^{27}$ Op andere fronten ging het bergafwaarts. Er werd bijvoorbeeld steeds meer bekend over pogingen van het Witte Huis om Lewinsky een aantrekkelijke baan te bezorgen, daags nadat zij voor het eerst was opgeroepen te getuigen in de zaak die Jones had aangespannen. Dat was té toevallig en riekte naar omkoping. Een beroep van Clinton en zijn medewerkers op 'executive privilige' om niet voor een 'grand jury' (een jury die moet oordelen over het al dan niet vervolgen van een verdachte in een strafzaak) te hoeven getuigen, liep op niets uit. Steeds meer leden van de staf van het Witte Huis, onder wie zijn secretaresse Betty Currie, zagen zich genoodzaakt onder ede - en dus naar waarheid - hun verhaal te doen. Lewinsky bereikte eind juli een akkoord met Starr over 'immunity' en sprak daarna vrijuit. Uiteindelijk kreeg ook Clinton zelf een dagvaarding. Zou hij weigeren of toegeven? Bij weigering hing hem juridische dwang tot getuigen boven het hoofd, en dat werd hem toch te gortig. Voor hemzelf én voor het presidentschap zou het een te grote vernedering zijn als hij naar de rechtszaal werd gesleept. Daarom toonde hij zich onder bepaalde voorwaarden bereid vrijwillig voor de 'grand jury' te verschijnen. En zo geschiedde. De leden van de jury waren zelf niet in het Witte Huis aanwezig, maar volgden het verhoor via een gesloten televisiecircuit. ${ }^{28}$

Vrijwillig getuigen was al ontluisterend genoeg. De vragen die de president voorgeschoteld kreeg waren van zeer intieme aard. Clinton zat er dus bij alsof hij zijn laatste oortje had versnoept. Van de politieke vechtjas was op dat moment weinig te bespeuren. Het dieptepunt kwam toen hij moest vertellen wat er werkelijk tussen hem en Lewinsky was voorgevallen en van welke aard hun contact was geweest. Op de definitie van 'sexual relations' - die immers door Clinton onder ede waren ontkend - werd uitgebreid ingegaan. Vertelt $u$ eens, meneer de president, valt orale seks daar volgens $u$ nu wel of niet onder? Het eerder met Starr bereikte akkoord stond hem gelukkig toe niet op elk detail in te gaan, maar te volstaan met het voorlezen van een tekst die 'alles maar niet alles' beloofde te onthullen:

'When I was alone with Ms. Lewinsky on certain occasions in early 1996, and once in early 1997, I engaged in conduct that was wrong. These encounters did not consist of sexual intercourse. They did not constitute sexual relations, as I 
understood that term to be defined at my January I7th, I998 deposition. But they did involve inappropriate, intimate contact. These inappropriate encounters ended at my insistence in early I997. I also had occasional telephone conversations with Ms. Lewinsky that included inappropriate sexual banter. I regret that what began as a friendship came to include this conduct. And I take full responsibility for my actions. While I will provide the grand jury whatever other information I can, because of privacy considerations affecting my family, myself and others, and in an effort to preserve the dignity of the office I hold, this is all I will say about the specifics of these particular matters. I will try to answer to the best of my ability other questions, including questions about my relationship with Ms. Lewinsky, questions about my understanding of the term of sexual relations, as I understood it to be defined at my January I7th, I998, deposition, and questions concerning alleged subordination of perjury, obstruction of justice and intimidation of witnesses. ${ }^{29}$

In zijn memoires blikt Clinton op dit moeilijkste der moeilijke momenten terug met de woorden:

'(...) Starr and his interrogators did their best to turn the videotape into a pornographic home movie, asking me questions designed to humiliate me and to so disgust the Congress and the American people that they would demand my resignation (...). 30

Meteen na zijn sessie met de 'grand jury' gaf Clinton op de televisie zijn 'inappropriate relationship with Monica Lewinsky' toe. Hij kon ook moeilijk anders. Wat de 'grand jury' had gehoord zou toch bekend zijn geworden, en dan was het maar beter gauw door de zure appel heen te bijten. Het waren sowieso droeve dagen voor Clinton. Zijn laatste verdedigingslinie bezweek onder de afgedwongen getuigenissen van zijn stafleden; Lewinsky droeg een jurk met spermavlekken over aan Starr en zelf moest hij DNA-materiaal afstaan dat zou worden vergeleken met het DNA van het materiaal op de jurk. Er ging geen dag voorbij of er gebeurde wéér iets waardoor de 'independent counsel' dichter bij zijn doel kwam.

Waaruit bestond dat doel? Starr had inmiddels besloten het Huis van Afgevaardigden, waaraan hij zou moeten rapporteren, aan te moedigen tot impeachment' van Clinton. ${ }^{3 \mathrm{I}}$ Als het Huis daaraan gevolg zou geven, zou de Senaat volgens de Grondwet als rechtbank - onder voorzitterschap van de 'Chief Justice' - fungeren, die na afweging van alle feiten eventueel zou overgaan tot afzetting van de president. ${ }^{32}$ De kans dat het door de Republikeinen gedomineerde Huis van Afgevaardigden inderdaad voor 'impeachment' zou stemmen achtte Starr reëel. Clinton zou dan de tweede officieel aangeklaagde president in de geschiedenis worden. Andrew Johnson (I865-I869) was hem voorgegaan (wel 'impeached', maar in de Senaat met een verschil van één stem aan de dans 
van afzetting ontsprongen; Nixon hield in 1974 de eer aan zichzelf toen hij aan zag komen dat het Huis hem zou aanklagen). Het rapport (Referral of the Independent Counsel) dat Starr op 9 september I998 aan het Huis voorlegde maakte al in de inleiding duidelijk waar het hem om te doen was:

'This Referral presents substantial and credible information that President Clinton criminally obstructed the judicial process, first in a sexual harassment lawsuit in which he was the defendant and then in a grand jury investigation. The opening section of the Narrative provides an overview of the object of the President's cover-up, the sexual relationship between

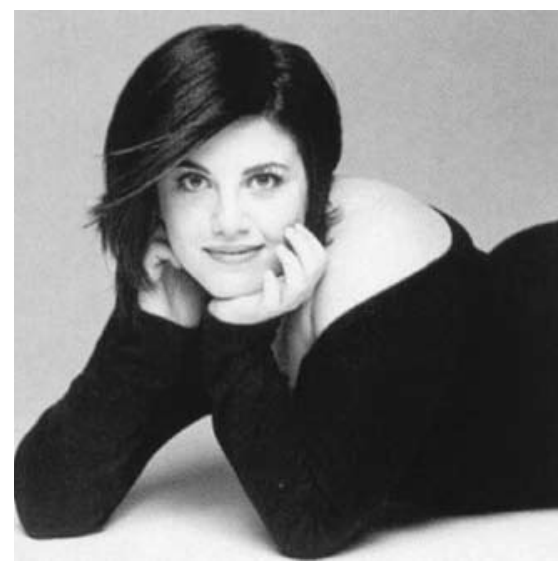

Monica Lewinsky the President and Ms. Lewinsky. Subsequent sections recount the evolution of the relationship chronologically, including the sexual contacts, the President's efforts to get Ms. Lewinsky a job, (...) the President's attempts to coach a potential witness in the harassment case, the President's false and misleading statements to aides and to the American public after the Lewinsky story became public, and, finally, the President's testimony before a federal grand jury.' 33

\section{Impeachment}

Het eerste dat het 'House Judiciary Committee', voorgezeten door de Republikein Henry Hyde, na ontvangst van Starrs rapport deed was het vrijgeven van het hele onderliggende dossier. Ook de videoband van Clintons getuigenis voor de 'grand jury' werd onder luid protest van de meeste Democraten in het Huis openbaar gemaakt. Wat Lewinsky tegen de 'grand jury' had gezegd, de foto's van haar bevlekte jurk, de schriftelijke neerslag van haar gesprekken met Linda Tripp, alles lag nu op straat. De gretigheid waarmee, en de manier waarop de Republikeinse meerderheid van het Huis de 'impeachment' in gang zette wees op een streven naar de totale vernedering van Clinton. De politieke bijbedoelingen werden eens te meer duidelijk in de campagne voor de Congresverkiezingen die in november zouden plaatsvinden. Alle Republikeinen roerden op volle kracht de trom van de Lewinsky-affaire. Daarnaast was er ook een klein aantal Democraten dat zich van Clinton distantieerde. Toen het voltallige Huis van Afgevaardigden op 8 oktober moest stemmen over het op touw zetten van een 'impeachment'-onderzoek, wezen I76 Democratische leden van het Huis zo'n onderzoek af en stemden er $2 \mathrm{I}$ voor.

Starr had in zijn rapport elf gronden voor 'impeachment' opgesomd, waarvan de vijf belangrijkste waren: 
'I. President Clinton lied under oath in his civil case when he denied a sexual affair, a sexual relationship, or sexual relations with Monica Lewinsky.

2. President Clinton lied under oath to the grand jury about his sexual relationship with Ms. Lewinsky.

(...)

5. During the Jones case, the President obstructed justice and had an understanding with Ms. Lewinsky to jointly conceal the truth about their relationship by concealing gifts subpoenaed by Ms. Jones's attorneys.

6. During the Jones case, the President obstructed justice and had an understanding with Ms. Lewinsky to jointly conceal the truth of their relationship from the judicial process.

(...)

II. President Clinton abused his constitutional authority by (i) lying to the public and the Congress in January I998 about his relationship with Ms. Lewinsky; (ii) promising at that time to cooperate fully with the grand jury investigation;

(iii) later refusing six invitations to testify voluntarily to the grand jury; (iv) invoking Executive Privilege; (v) lying to the grand jury in August I998; and (vi) lying again to the public and Congress on August I7, I998 - all as part of an effort to hinder, impede, and deflect possible inquiry by the Congress of the United States.' 34

De kern van de beschuldigingen was volgens Starr 'obstruction of justice' in de civiele zaak van Paula Jones tegen de president (vanwege diens 'sexual harassment' van jaren her). Het ging hem zogenaamd niet om de affaire tussen Clinton en Lewinsky en al helemaal niet om seks, maar om het feit dat Clinton in zijn pogingen om Jones van zich af te schudden én zijn overspel geheim te houden, Lewinsky had geïnstrueerd om hun relatie te ontkennen. Clintons advocaten kwamen tijdens het 'impeachment'-onderzoek van het Huis met het verweer dat Starr juist geobsedeerd was geweest door de seksuele aspecten van het Lewinsky-schandaal:

'(...) "sex" is precisely what this four-and-a-half year investigation [het Whitewater-onderzoek, D.B.] has boiled down to. The referral is so loaded with irrelevant and unnecessary graphic and salacious allegations that only one conclusion is possible: its principal purpose is to damage the President.'35

De verkiezingen op 3 november liepen voor de Republikeinen op een grote teleurstelling uit. Tegen alle prognoses in verloren zij vijf zetels in het Huis van Afgevaardigden. In de Senaat bleven de zeteltallen ongewijzigd. Dit was het netto-resultaat; in de gevallen waarin een Senaatszetel van een Republikein overging naar een Democraat bleek uit de exit-polls en ander onderzoek dat dit in de meeste gevallen een afstraffing voor het stemmen voor afzetting van de president behelsde. De meest uitgesproken tegenstander van Clinton 
en promotor van het 'Contract with America', 'Speaker' (Voorzitter van het Huis) Newt Gingrich, werd wel herkozen, maar besloot zijn zetel niet te aanvaarden. ${ }^{36}$

Meteen hierna begonnen Clintons kansen te keren. Weliswaar aanvaardde het 'House Judiciary Committee' op II en I2 december vier 'articles of impeachment', maar het feit dat het voltallige Huis (nog in zijn oude samenstelling) op I9 december twee van die vier artikelen liet vallen, duidde op afnemend enthousiasme voor een frontale aanval. Op 7 januari I999 begon het proces in de Senaat, onder leiding van 'Chief Justice' William Rehnquist. Het eindigde op I2 februari met een dubbel 'not guilty'. Voor afzetting zou een twee-derde meerderheid voor een van de 'articles' moeten hebben gestemd. Geen van de artikelen haalde echter zelfs maar een gewone meerderheid. Tien Republikeinen stemden samen met alle Democraten (45) tegen een veroordeling wegens meineed en vijf van hen stemden ook tegen het artikel dat Clinton betichtte van 'obstruction of justice'. De nederlaag voor Starr was compleet. Voor de president betekende dat nog geen complete overwinning. Daarvoor was er teveel gebeurd. In een poging een streep onder de zaak te zetten bood Clinton officieel zijn excuses aan ('I am profoundly sorry') aan het Congres en aan het Amerikaanse volk.

\section{De media}

De meest kritische kijk op de rol van de media in deze affaire is die van Bill Kovach en Tom Rosenstiel. ${ }^{37}$ In hun boek Warp Speed dragen zij argumenten aan voor de theorie dat het Lewinsky-schandaal de overwinning betekende voor een nieuwe mediacultuur ('the mixed media culture'), waarin de nieuwsgaring door de pers is vervangen door een 'continuous news cycle'. ${ }^{8}$ Serieus nieuws, 'infotainment' en 'spin' zijn niet meer van elkaar te onderscheiden. De verschillende soorten nieuws worden in moordend tempo als dakpannen, maar dan schots en scheef, over elkaar gelegd. De oude vertrouwde gatekeeper/journalist staat met lege handen; de nieuwsconsument mag het allemaal zelf uitzoeken. De affaire rond O.J. Simpson - I7 juni I994 keek heel Amerika toe hoe 'O.J.' in zijn Ford Bronco door de politie werd achtervolgd - was de eerste waarin deze chaos zich manifesteerde. Volgens Kovach en Rosenstiel markeerde het Lewinsky-schandaal het moment waarop de 'post O.J. media culture' zich vermengde met de landelijke politiek.

Er is wel wat op deze visie af te dingen. Welbeschouwd hebben de media bij het ontstaan van het schandaal een betrekkelijk terughoudende rol gespeeld. Daar hoeft ook niemand vreemd van op te kijken, want de affaire was groot genoeg van zichzelf; deze hoefde niet te worden opgeblazen om besmuikte interesse te wekken. Media die Clinton bij uitstek vijandig gezind waren deden hun best de politieke aspecten uit te vergroten, maar al gauw bleek dit onbegonnen 
werk. Daarna gaven zij blijk van teleurstelling over het gebrek aan moreel besef van het Amerikaanse publiek, omdat dit Clinton zoveel krediet bleef geven. ${ }^{39}$

Het was eigenlijk een internetkrant (Drudge Report van Matt Drudge) die het schandaal het eerst in de openbaarheid bracht, dus nog voordat The Washington Post op 2I januari I998 de alarmbellen deed afgaan. Drudge maakte bekend dat Newsweek op het laatste moment had afgezien van een explosief artikel over Clinton en een minnares. Dit verhaal klopte; Newsweek kende de belangrijkste feiten, inclusief de rol van Linda Tripp met haar cassettebandjes, maar was voor publicatie teruggeschrokken omdat niet alles kon worden geverifieerd. De openbaarheid die Drudge creëerde was slechts betrekkelijk, want ten eerste had Drudge Report qua betrouwbaarheid geen beste naam, wat een reden was om ook in dit geval aan roddel te denken. Ten tweede wisten velen in I998 nog geen raad met internet. Was het serieus of was het dat niet? Vandaag de dag verspreidt internetnieuws zich sneller dan toen het geval was, omdat alle belangrijke media zich ook van internet bedienen.

Zonder de berichtgeving via televisie, radio en geschreven pers zou het schandaal niet op gang zijn gekomen, maar die conclusie trapt een open deur in. Hetzelfde geldt voor de constatering dat de berichten vaak sensationeel waren. Er bestaat nu eenmaal een categorie nieuws die moeilijk anders dan sensationeel gebracht kan worden. Voor zover er iets werd aangedikt, was dat mede een teken van verder voortgeschreden commercialisering van het hele nieuwsbedrijf. Gelukkig waren er altijd nog kwaliteitskranten die de discussie over de consequenties van wat er was gebeurd in rustiger vaarwater trachtten te loodsen. Zij deden dit onder andere door de geloofwaardigheid van getuigen zorgvuldig te wegen. Dankzij dat soort behoedzaamheid viel bijvoorbeeld Kathleen Willey, een vrouw die probeerde munt te slaan uit het schandaal door te verklaren dat Clinton zich ook tegenover haar schuldig had gemaakt aan seksuele intimidatie, door de mand. ${ }^{\circ}$

De zogenoemde 'networks' (АBC, СвS, NBC), die naast hun taak nieuws te brengen ook nog hun (commercieel interessantere) verstrooiende functie hebben, probeerden onpartijdig te zijn. Slaagden zij daarin? In satirische programma's, om één voorbeeld te noemen, was het bijna onmogelijk de unieke mogelijkheden die dit schandaal bood zo te benutten dat het resultaat 'objectief' was. In categorieën als drama en documentaire kan het product in principe evenwichtiger zijn, maar in de praktijk is daar weinig van gebleken.4 ${ }^{\mathrm{I}}$

Om het voorgaande samen te vatten: de stelling van Lull en Heinerman dat 'de' media stelselmatig uit zijn op het creëren van schandalen, wordt door het Lewinsky-schandaal niet bevestigd. ${ }^{42}$ Het lijkt erop dat de kwestie alom zo gênant, precair en constitutioneel riskant werd gevonden, dat alleen de media met duidelijke politieke doelstellingen hun kans grepen. 'De' media lieten hun aanvankelijke gretigheid op een gegeven moment varen. Nog afgezien van het aspect van gêne had Amerika in de recente geschiedenis genoeg schandalen beleefd om niet te hunkeren naar een volgend. 
In de inleiding van dit artikel werd opgemerkt dat de Amerikaanse preoccupatie met seks een voorwaarde was voor het ontluiken van het schandaal. Die preoccupatie is een feit en dat zij bij het ontstaan van de affaire een cruciale rol heeft gespeeld staat eveneens vast. Maar ook valt te constateren dat het Amerikaanse publiek zich minder door het pikante aspect van de zaak heeft laten meeslepen dan misschien te verwachten was. Zo nuchter als Europese toeschouwers er waarschijnlijk mee om zouden zijn gegaan bleef het niet; uiteindelijk is zijn pekelzonde Clinton echter vergeven. Hoofdzaak werden, en bleven, het liegen onder ede, het liegen tegenover de pers en het belemmeren van de rechtsgang in de civiele zaak 'Jones vs. Clinton'. Naar Europese maatstaven stelde het Amerikaanse publiek zich daarin zeker niet overdreven streng op. In tegendeel. Nogal wat Europese commentatoren waren van mening dat Clinton vrij makkelijk wegkwam met zijn verstoring van de rechtsgang. 43 Wel was er algemene afkeuring van het onderzoek van Starr. Een 'independent counsel' die zoveel macht naar zich toetrok en het politieke motief zozeer liet prevaleren zou in Europa veel eerder zijn teruggefloten.

De gemiddelde Amerikaanse burger heeft zich in heel I998 op geen enkel moment door het Lewinsky-schandaal van de wijs laten brengen. De emotionele betrokkenheid was voor zover die uit opiniepeilingen viel op te maken betrekkelijk gering, of de uitwerking van met elkaar botsende emoties was neutraal. Zelfs op het dieptepunt van de affaire, toen Clinton door Starr tegen de touwen was gebokst en alles wat hij op zijn kerfstok had in de krant had gestaan, handhaafde zijn 'approval rating' zich boven de zestig procent. 44 Het blijft ondanks alle wetenschappelijke analyse die erop is losgelaten, speculeren hoe hij dit voor elkaar heeft gekregen. 45 Clinton kon in ieder geval bogen op een geslaagd economisch beleid. In zijn State of the Union van 27 januari I998, zes (!) dagen nadat The Washington Post gewag had gemaakt van een verband tussen de Paula Jones-zaak en Monica Lewinsky, durfde hij het aan om met geen woord naar deze kwestie te verwijzen. In plaats daarvan presenteerde hij met veel bravoure een overzicht van zijn onbetwistbare successen, waaronder het feit dat er voor het eerst sinds vele decennia een evenwicht op de begroting was bereikt. Voor I999 viel zelfs een royaal overschot te verwachten. En dat alles zonder dat hij in sociaal opzicht concessies had hoeven doen. In de meest bevlogen 'State of the Union' van zijn achtjarige presidentschap schetste hij een Amerika dat sterk leek op wat Lyndon Johnson in de jaren '6o met zijn 'Great Society' voor ogen had gestaan, maar dat in het moeras van Vietnam was verdronken. Uit de opiniepeilingen in de weken na dit optreden bleek het zijn uitwerking niet te hebben gemist. De waardering voor zijn 'performance' schoot omhoog.

Dat een groot deel van het publiek zich duidelijk distantieerde van Clintons gedrag (overspel, leugens) en dit zonder voorbehoud 'immoreel' noemde, stond waardering voor zijn persoon én voor zijn presidentschap niet in de weg. 
Naarmate Starr zich meer en meer partijdig toonde en het verband tussen het Whitewater-onderzoek en zijn acties tegen Clinton zoekraakte, neutraliseerde het ressentiment tegen de 'independent counsel' alle negatieve berichtgeving over de president. Dit gold de overgrote meerderheid van Democraten, naast een minderheid van Republikeinen die zich wat meer aan de onderkant van de sociale ladder bevonden, maar het gold heel in het bijzonder de African-Americans. Deze laatste bevolkingsgroep beschouwde de man uit Arkansas, die het ondanks zijn uiterst bescheiden komaf ver geschopt had, als 'een van hen'.

'Certain symbolism at the core of the Lewinsky story might explain deeper levels of African-American support for Clinton, for many blacks may have seen in Clinton's travails a reflection of their own experiences with the American criminal justice system', zeggen Lawrence en Bennett. ${ }^{6}$

Ook met zijn beleid, dat consequent op het verbeteren van hun lot gericht was geweest, had Clinton hun vertrouwen gewonnen. De spreker Clinton sprak bovendien hun taal. Als 'Southern Baptist' hanteerde hij de retoriek die zij in hun naaste omgeving gewend waren. Maar het belangrijkste was dat hij in zijn pleidooien voor een ander, beter Amerika meende wat hij zei. Dat had hij in zijn lange politieke carrière wel bewezen.

Populariteit is altijd relatief. Clinton was ook in absolute termen een geliefde president, maar het hielp wel dat zijn belangrijkste tegenstanders (Starr, Gingrich, Hyde) ronduit impopulair waren en dat geen enkele opponent zich qua populariteit met hem konden meten. Het uiteindelijke oordeel van het publiek over de vraag of hij afgezet moest worden was de resultante van een afweging. Tegenover de argumenten 'voor' stonden de argumenten 'tegen'. Bij het wegstrepen van het een tegen het ander prevaleerden de laatste zo sterk dat alle antwoorden samen neerkwamen op 'zeker niet'. De afweging die men moest maken was van persoonlijke aard en dus niet objectief. Peilingen van Gallup wezen uit dat de royale meerderheid die achter Clinton bleef staan uiteenviel in diverse groepen, waaronder 'admirers' ( 26 procent), 'pragmatists' (I8 procent) en 'forgivers' (ook I8 procent). In de middelste groep werd het negatiefst gedacht over Clinton als persoon, maar ook de laatste groep had van hem als mens geen hoge dunk. 47

Zou het anders met Clintons populariteit gesteld zijn geweest als Starr hem niet tot underdog had gemaakt? Ook dat is moeilijk te zeggen, want was Clinton wel de underdog? De 'independent counsel' smeet met belastinggeld, stelde zich afstandelijk op, deed weinig moeite zich te rechtvaardigen en stootte ook nog wel eens zijn neus bij een rechter die vond dat hij te ver ging. Echt geliefd was hij bij niemand. In zijn conflict met Clinton was het steeds zijn prestige tegen dat van de president, en in die krachtmeting was er geen evidente winnaar. De paradox van hun relatie was dat de underdog Clinton steeds een zekere vorm van superioriteit bleef demonstreren. Dus wie lag nu eigenlijk onder? 
Mede door de strijd aan te gaan heeft Clinton zijns ondanks bewijzen aangedragen dat 'het systeem werkte'. Het Lewinsky-schandaal heeft veel nieuwe jurisprudentie opgeleverd over de relatie tussen de uitvoerende en de wetgevende macht, waardoor I998-I999 niet alleen een lastige, maar ook een heel interessante periode is geworden. Konden alleen de grootste optimisten na 'Watergate' beweren dat Amerika sterker uit die affaire te voorschijn was gekomen, na het Lewinsky-schandaal was dat helemaal niet zo'n loze kreet. Natuurlijk kan dit 'succes' bezwaarlijk op Clintons conto worden geschreven, maar voor Starr geldt eigenlijk hetzelfde.

\section{Epiloog}

Clinton gaat in $M y$ Life, zijn autobiografie, terughoudend in op het Lewinskyschandaal. Over de aard van zijn relatie met Lewinsky bewaart hij het stilzwijgen, afgezien van de erkenning dat hij 'inappropriate encounters' met haar had, wat gezien zijn verklaring voor de 'grand jury' geen nieuws is. Woede over Starrs dubieuze manier van werken, voldoening over het feit dat hij het Congres heeft getrotseerd en niet is afgetreden en overvloedig beleden schaamte overheersen. ${ }^{8}$ Ook bij andere gelegenheden heeft hij laten merken dat hij zich schaamt. Op een vraag van Dan Rather (in 60 MiNUTES) naar het waarom van de affaire tussen een volwassen man, die ook nog eens president van de Verenigde Staten was, en een 2I-jarige stagiaire, zei hij in 2004: 'I think I did something for the worst possible reason - just because I could.'49

Tussen hem en Lewinsky zal het niet meer goed komen. De koele en afstandelijke manier waarop hij zich over hun relatie uitlaat, miskent volgens haar dat zij werkelijk een 'mutual relationship' hadden. Zij voelt zich ernstig tekortgedaan door wat het kamp van Clinton over haar zei in de periode dat hij nog vocht voor zijn overleving als president. Over Starr is haar opinie overigens nog negatiever, want diens handelwijze heeft haar praktisch kapotgemaakt.

Het Lewinsky-schandaal was al met al een tragische aangelegenheid met bijna uitsluitend verliezers. Lewinsky zelf - misschien niet in elk opzicht onschuldig, maar zeker gezien haar leeftijd toch vooral slachtoffer - raakte een grote liefde kwijt en had na alles wat haar was overkomen grote moeite weer op te krabbelen. Clinton viel als mens door de mand. Zijn rol getuigde vanaf het begin al niet van verantwoordelijkheidsbesef. Toen het schandaal uitdijde gedroeg hij zich kleinzielig, hoezeer hij er ook als politicus in slaagde zich niet alleen te handhaven, maar van de nood zelfs een deugd te maken - zijn populariteit nam eerder toe dan af. Kenneth Starr verloor zijn reputatie, door eigen schuld. Als hij van zijn Whitewater-onderzoek geen persoonlijke vete met Clinton had gemaakt, als hij geen God had willen spelen, was het beter met hem afgelopen. De Republikeinse volksvertegenwoordigers waren de grootste verliezers. Door Clinton grotendeels - de oprecht bezorgde leden van Huis en 
Senaat niet te na gesproken - om politieke redenen op te jagen, overspeelden zij hun hand en zetten zij de 'Republican Revolution' van i994 op het spel.

Zoveel verliezers bij en naast elkaar. Het heeft iets van wat Amerikanen 'poetic justice' noemen.

\section{Noten}

I De functie van 'independent counsel' wordt in de Kenneth Starr-paragraaf hierna toegelicht.

2 James Lull and Stephen Hinerman, 'The Search for Scandal' in: J. Lull \& S. Hinerman (eds.), Media Scandals. Morality and desire in the popular culture marketplace, New York I998, p. I-33 (p. 9).

3 Mary P. Ryan, Mysteries of Sex: Tracing women \& men through American history, Chapel Hill 2006, geeft een goede introductie op dit thema.

4 Zowel ten tijde van het Watergate-schandaal (I972-I974) als daarna streefde de Republikeinse Partij ernaar de daden van Nixon als menselijke tekortkomingen te definiëren.

5 In 'Section 4' van het tweede artikel van de 'Constitution of the United States' staat het als volgt: 'The President, Vice President, and all civil officers of the United States shall be removed from office on impeachment for, and conviction of, treason, bribery, or other high crimes and misdemeanors.'

6 Doordat de 'approval rating' van Clinton steeds hoog bleef, is het moeilijk het moment aan te geven waarop de stemming omsloeg van 'een goede president die een ernstige fout heeft gemaakt' naar 'een goede president die om politieke redenen wordt vervolgd'. Algemeen wordt aangenomen dat de openbaarmaking van Clintons getuigenis voor de 'grand jury' in de zomer van I998 de stemming sterk in zijn voordeel heeft beïnvloed, want dat was het moment waarop hij de echte underdog werd.

7 Het qua conclusies gekleurde, maar door zijn compleetheid toch zeer informatieve rapport van Kenneth Starr verscheen in september I998. Het telde 450 pagina's en omvatte alle details inzake ook de meest intieme aspecten van de relatie tussen Clinton en Lewinsky.

8 Zo blijkt uit diverse onder ede afgelegde getuigenissen, te vinden in het rapport van Kenneth Starr.

9 In het Starr-rapport is sprake van in totaal vijftig telefoongesprekken en 'phone sex' tijdens tien à vijftien van die gesprekken.

Io Uit het Starr-rapport, geciteerd in bijna alle krantenverslagen en op Internet: http://www. time.com/time/magazine/article/o,9I7I,989120-6,00.html.

II De wet specificeerde de overheidsfunctionarissen wier handelen in aanmerking kwam voor deze procedure.

I2 Us Code Collection, Title 28, Part II, Chaper 40, Par. 594 http://www.law.cornell.edu/ uscode/html/uscode28/usc_sec_28_00000594----ooo-.html.

I3 Het 'Whitewater'-onderzoek heeft aan het eind van de rit wel veroordelingen opgeleverd, maar de Clintons gingen geheel vrijuit.

I4 De 'Special Division of the District of Columbia circuit'.

I5 Zie: Michael Tomasky, 'Can we know her?', The New York review of Books, I7 juli 2007, p. I4I6 (p. I6). Dit is een recensie-artikel over een aantal boeken met Hillary Clinton als onderwerp, waarin ook de Whitewater-affaire aan de orde komt.

I6 Een dergelijk kritisch oordeel was te vinden in alle vooruitstrevende kranten, maar ook gematigde conservatieven als Andrew Sullivan koesterden dit standpunt. Zie het stuk van Sullivan in The New York Times van II oktober I998. http://query.nytimes.com/gst/fullpage.html?res=950 ${ }_{5} \mathrm{E}_{2 \mathrm{DD}} 6_{3} \mathrm{BF}_{932 \mathrm{~A} 25753 \mathrm{CiA}_{9} 6 \mathrm{E}_{95} 8260 .}$

I7 Benjamin Wittes, Starr: A Reassessment, New Haven 2002. 
I8 Talloos zijn de karikaturen (spotprenten) geweest waarin Tripps uiterlijk werd aangegrepen om de karakterloosheid van haar handelen te onderstrepen.

I9 Dit is door getuigenissen onder ede vast komen te staan en Clinton heeft het ook toegegeven in zijn officiële schuldbekentenis.

20 Eerder had Drudge Report, een internetkrant, er al iets over bericht.

2I The Washington Post, 2I januari I998, p. I.

22 Geciteerd in het Starr Report (voor de verwijsplaats zie noot IIO2 van het rapport).

23 Deze scène werd op prime time rechtstreeks op de televisie gebracht.

24 Geciteerd in het Starr Report, noot iI6o.

25 http://edition.cnn.com/AllPolitics/i998/or/27/hillary.today/ (I-8-o7).

26 In zijn memoires meldt Clinton dat hij Hillary pas op I5 augustus, dus slechts een paar dagen voor zijn getuigenis voor de 'grand jury', de waarheid heeft verteld. Bill Clinton, My Life, New York 2004, p. 800-80I.

27 Clinton kocht Jones later af met een bedrag van een kleine miljoen dollar. Daarnaast veroordeelde een rechter hem tot betaling van een forse boete wegens liegen onder ede (over zijn relatie tot Lewinsky) in Jones' zaak tegen hem. Ook moest hij de reiskosten vergoeden van de rechter die in het Witte Huis zijn 'grand jury'-getuigenis had voorgezeten.

28 Deze getuigenis werd afgelegd op I7 augustus I998.

29 Op audio: http://www.cnn.com/icreport/\#I.

30 Clinton, My Life, p. 8oI

3I De Grondwet legt 'the sole power to impeach' bij het Huis van Afgevaardigden. Op 'impeachment' in het Huis volgt een 'trial' in de Senaat.

32 Zoals de Grondwet zegt: "The Senate shall have the sole Power to try all Impeachments. When sitting for that Purpose, they shall be on Oath or Affirmation. When the President of the United States is tried, the Chief Justice shall preside: And no Person shall be convicted without the Concurrence of two thirds of the Members present.'

33 Met deze zinnen begint de Inleiding van het rapport.

34 Hiermee meende Starr aan zijn opdracht als 'independent councel' te voldoen, getuige de aanhef van dit hoofdstuk in het rapport: 'Pursuant to Section 595(c) of Title 28 , the Office of Independent Counsel (OIC) hereby submits substantial and credible information that President Clinton obstructed justice during the Jones v. Clinton sexual harassment lawsuit by lying under oath and concealing evidence of his relationship with a young White House intern and federal employee, Monica Lewinsky.'

35 'Initial Response to the Referral of the Office of Independent Counsel', p. I.

36 Gingrich was een van degenen die heilig geloofden in de Lewinsky-affaire als Republikeinse goudmijn. Verwijzend naar het schandaal zei hij in april I998 dat 'I will never again, as long as I am Speaker, make a speech without commenting on this topic'.

37 Voorzitter en vice-voorzitter van het kritische 'Committee of Concerned Journalists'.

38 Bill Kovach en Tom Rosenstiel, Warp Speed. America in the Age of Mixed Media. With a Preface by David Halberstam, New York 1999.

39 Zie bijvoorbeeld een hele serie commentaren van William F. Buckley jr. in de National Review.

40 Zie de stukken van Jill Abramson en Don Van Natta jr. in The New York Times; onder meer 20 maart 1998.

4I Wat te denken van een miniserie (The Path to 9/11) die ABC precies vijf jaar na de aanslagen van II september 200I uitzond en waarin feitelijk steun werd gegeven aan oude Republikeinse beschuldigingen als zou niet Bush, maar Clinton terroristen als Bin Laden teveel hun gang hebben laten gaan? Onder Clinton zou het terroristische gevaar stelselmatig zijn onderschat, wat mede kwam doordat de toenmalige president zelf de handen vol had aan het Lewinsky-schandaal.

42 Zie de openingsparagraaf.

43 NRC Handelsblad en de Volkskrant spraken bijvoorbeeld beide in verband met Starrs belangstelling voor Clintons seksuele moraal regelmatig van een 'heksenjacht', maar vonden eveneens allebei dat Clinton ver over de schreef gegaan was door onder ede te liegen. 
44 Regina Lawrence \& W. Lance Bennett, 'Rethinking Media Politics and Public Opinion: Reactions to the Clinton-Lewinsky Scandal' in: Political science Quarterly II6 (200I) 3, p. 425-446 (p. 425).

45 Zie naast het in de vorige noot genoemde artikel onder meer: Arthur H. Miller, 'Sex, Politics, and Public Opinion: What political scientists really learned from the Clinton-Lewinsky scandal' in: PSOnline, december I999, p. 72I-729.

46 Lawrence \& Bennett, 'Rethinking Media Politics', p. 440.

47 Irwin L. Morris, Votes, Money, and the Clinton Impeachment, Boulder 2002, p. 53-54.

48 Bill Clinton, My Life, New York 2004.

49 http://www.cbsnews.com/stories/2004/06/16/eveningnews/main623570.shtml (I-8-o7). 